\title{
Listening Comprehension Ability and Language Attitudes: American vs. British English
}

\begin{abstract}
Fei-Hsuan Liao
Rou-Jui Sophia Hu

Chienkuo Technology University, Taiwan, R.O.C.

Cheng Shiu University, Taiwan, R.O.C.

American English is predominantly prescribed as the primary English learning model at every educational level in Taiwan and limited attention is paid to other accents of English. It is therefore the intention of this paper to investigate whether Taiwanese EFL learners have difficulties understanding British English after years of instruction in American English, and to identify differences between learners' attitudes towards these two varieties of English. EFL learners from two universities were randomly assigned to American and British English groups and required to listen to short texts recorded with either American or British accent. An independent simple t-test showed that no significant differences were found in listening comprehension scores, but responses on questionnaires revealed significant differences in attitudes towards American and British English. The influence of long-term instruction in American English was evidenced. Based on these findings, suggestions are provided for English language teaching in Taiwan and implications are drawn for the concept of English as an International Language (EIL), that in order to pursue successful international communication with people of various native languages, EFL learners need to experience various accents of English.
\end{abstract}

Keywords: listening comprehension, accents of English, American English, British English

\section{Introduction}

English has become an international language over the last century, and a huge number of non-native learners have strived to acquire the lingua franca (Jenkins, 2006, 2009, 2012) to pursue global communication. Taiwanese educators and business people have made great efforts to follow the trend. Due to the close relationship and frequent contact between Taiwan and the United States in political, economic, and cultural affairs, American English has been prescribed as the predominant English learning model at all education levels.

However, English varieties with differences in accents, lexical items, or even grammatical properties exist. As such, it is problematic to choose which learning model should be prescribed and whether learners can understand another English variety if they are so accustomed to one accent. Hence, it may provide valuable pedagogic insights to investigate whether Taiwanese EFL learners have difficulties understanding British English after long-term exclusive instruction in American English. In addition, learners' attitudes towards American and British English may provide useful information for classroom instruction even though they do not have much opportunity to learn or experience British English. Before the presentation of current research, a

Fei-Hsuan Liao, associate professor, Ph.D., The Department of Applied Foreign Languages, Chienkuo Technology University. Rou-Jui Sophia Hu, associate professor, M.A., The Department of Applied Foreign Languages, Cheng Shiu University. 
literature review on the comparison between American and British English, or broadly, the comparison between various accents of English, will provide a solid theoretical foundation for this research.

\section{Literature Review}

English is now considered the lingua franca for international communication and the population of English language speakers can be said to be the largest among all languages. Above all, two major varieties prevail in English learning: American and British English. According to Kachru's classification, these two varieties are in the inner circle and are considered the two major norms for English speaking (Kachru, 1992, pp. 356-357). As opposed to these inner circle varieties, the outer circle refers to the varieties spoken in countries where English is taught as a second language, such as India, Singapore, and Ghana, while the expanding circle regard English as a foreign language that is speedily expanding its territory because of the growing status of English as the lingua franca (Jenkins, 2006, 2009, 2012). The countries in the so-called expanding circle would include Japan, Israel, Egypt, most European countries, and Taiwan. Among the varieties of English, it is logical to assume that EFL learners may have better comprehension of the varieties or accents with which they are familiar or which they are taught. It may be interesting to know whether EFL students can comprehend content spoken with familiar accents better than with unfamiliar ones. Because schools or government authorities may prescribe one variety over the others as the English learning model, EFL learners' comprehension of unfamiliar accents is always problematic. Investigations concerning this issue have been conducted to evidence this kind of difficulty.

One word on the status of American and British English is necessary. American English seems to have become more popular among non-native speakers since the United States of America emerged as the most culturally and economically influential country after World War II. American English is sometimes called General American (GA for short) because it refers to the variation that is spoken mostly beyond regional boundaries within the US. British English, on the other hand, refers to the official dialect that is spoken in the United Kingdom, including Great Britain and her territories in the British Commonwealth. The official variation, Received Pronunciation (RP for short), is recognized as the standard accent in order to be distinguished from a number of regional dialects in Britain.

The familiarity effect on English listening comprehension has been demonstrated in numerous studies. In the investigation into the effects of different English varieties on listening comprehension, subjects have been tested with standard American English, Southern American English, African American English, Australian English, and Indian English (Major, Fitzmaurice, Bunta, \& Balasubramanian, 2005). Since subjects were students who studied either language courses or graduate/undergraduate programs in the US, they were supposed to be more familiar with General American English. Regardless of different L1 backgrounds, listening comprehension test results have shown a level of significance between the varieties of English. It is therefore argued that the effect of familiarity could explain the differential comprehension ability of various dialects because this group of subjects was more exposed to General American English.

Similarly, this familiarity effect has also been found in Taiwanese subjects. Taiwanese researchers experimented with the contrast between American vs. British English. As has been mentioned, American English is prescribed exclusively as the English learning model at every educational level, and researchers wanted to see whether there would be a difference in listening comprehension ability for American and British English content (Chen, 2010). In the experiment, versions of American and British English for TOEIC listening 
comprehension tests were employed as materials. The result was found to be consistent with the researchers' expectation that students would score higher in the American English version. Similar findings were obtained in Heeren's study, in which, even after 10 weeks of training in American and British English, students performed better on TOFEL tests (American English) than on IELTS tests (British English) (Heeren, 2012).

Nevertheless, counter-evidence exists that could refute the familiarity effect on learners' listening comprehension ability. College students were tested on their understanding of American vs. Irish English (Matsuura, Chiba, \& Fujieda, 1999). Listening comprehension tests included partial dictation and comprehension checks. Among 106 subjects, only 36 students who were taught by an Irish teacher did not present higher dictation scores and thus the conclusion was reached that familiarity did not lead to better performance in listening comprehension.

In EFL, the comparison between the status of American and British English is actually more vigorously discussed with regard to the instruction of pronunciation than the issue of listening comprehension. It is worthwhile to mention these studies, in spite of the danger of digression, in that they may be seen to demonstrate counter-evidence of the effects of familiar accents.

Two Swedish investigations into the pronunciation tendency of American vs. British English revealed interesting results (Östlund, 2005; Alftberg, 2009). In Sweden during the period of research, British English was taught in school. In Östlund's study, a pronunciation test sheet was designed to reveal the pronunciation tendency of high school students. For instance, the /æ/ sound in American English would swift to /a:/ sound in British English. The researcher specifically put the differences into the test and found that the pronunciation of most learners actually mixed the two accents. The other Swedish research also involved an investigation of learners' pronunciation tendency (Alftberg, 2009). A pronunciation test sheet including 13 English words was intended to reveal learners' preferred accents. The results revealed that these 16 subjects used American English more frequently, although they had been taught British English. The researcher speculated that the much stronger preference for American English probably resulted from the omnipresent influence of media, such as television, the internet, music, and online games.

The results of these two Swedish studies support previous studies that claim Swedish learners tended to prefer and use more American English, even though British English was taught in the formal education system. These findings open up an intriguing issue of philosophical interests. How do we define "accents of familiarity"? Earlier studies clearly focus on the accent taught or prescribed in an educational system, but recent studies overturn this conception; due to the ubiquity of mass media, the accent that is more widely heard on TV or on the Internet can become more familiar.

Earlier research conducted in Brazil also found that EFL learners' oral production shift between American and British English (Mompean, 1997). In Brazil during the 1990s, American and British English were both recognized with equal status. In education, government administration, or even in daily life, both varieties were commonly used and spoken. In the experiment, subjects were required to first read a word list and then told a story that they were to record. It was found that more subjects presented mixed features of American and British English. For instance, while they were more inclined to produce the rhoticity of typical American pronunciation, subjects shifted between the American and British model. They tended to speak with the $/ \mathrm{p} /$ of British English, such as the vowel sound in words "box" and "not"; but a much stronger tendency occurred in the $/ \varepsilon /$ sound of American English, such as the vowel sound in words "red", "text", and "there". 
Apart from the investigation into the effects of familiar accents on listening comprehension and oral pronunciation, surveys have been conducted to reveal learners' attitudes towards both varieties. With a rich cultural and historical background, and the powerful influence of the British Empire over centuries, British English is regarded as superior, more formal, prestigious, and educated (Dalton-Puffer, Kaltenboeck, \& Smit, 1997; Ladegaard, 1998; Östlund, 2005; Scales, Wennerstrom, Richard, \& Wu, 2006; Alftberg, 2009; Rasmussen, 2015; Safaa, 2015). American English, on the other hand, is deemed informal, exciting, fascinating, socially attractive, and more useful in English language teaching. Although subjects might favor either American or British English, a trend is evident that American English is expanding its territory, thanks to the ubiquity of mass media, including broadcast media and digital media. The former includes television, radio, and films, while the latter mainly refers to the internet, which breaks through spatial and temporal limitations. The trend has been uncovered in a number of studies with regard to learners' perception and attitudes towards these two varieties of inner-circle English (Ladegaard, 1998; Östlund, 2005; Alftberg, 2009; Rasmussen, 2015).

In this study, we also aim to look into students' performance on listening comprehension tests of American vs. British English. It is expected that, since Taiwanese students are taught exclusively in American English, students' performance will be better on the American English version of tests. In addition, Taiwanese students' attitudes towards American and British English are also of great interest. Accordingly, the research questions are:

(1) Do Taiwanese EFL learners exhibit differential listening comprehension ability of American vs. British English?

(2) Are there any differences in Taiwanese EFL learners' attitudes towards American and British English?

(3) Is there any significant relationship between listening comprehension ability and attitudes towards American or British English?

\section{Methodology}

\section{Materials}

Existing listening training materials had been surveyed for this research, but no suitable materials were found. In particular, no materials were recorded with both American and British English. Therefore, it was decided that a self-designed listening comprehension test would be more plausible for this research. Short texts were preferred because they did not require heavy memory loading as to affect subjects' performance adversely. Eleven short passages were selected and recorded by both an American and a British native speaker. The length of recording time was tightly controlled in order to render consistent the speed of speaking. In the recordings, each passage is read twice, followed by one or two multiple-choice questions.

Also, in order to correlate listening comprehension ability to attitudes towards American and British English, 20 multiple-choice questions regarding the listeners' attitudes were formulated (see Appendix). Accordingly, the attitude-focused questionnaires were constructed to contain two parallel sections with regard to American and British English; 10 questions for each section were therefore conceived. A 5-point Likert scale was adopted so that every question was provided with five choices ranging from 1 to 5: (1) strongly disagree; (2) disagree; (3) no opinion; (4) agree; or (5) strongly agree. In order to ensure that participants could fully understand all questions and feel comfortable in providing reliable data, the questionnaire was written in their mother tongue (i.e., Mandarin). 


\section{Data Collection}

One hundred and fifty-one students from two universities were willing to participate in the experiment, and their proficiency levels ranged from low-intermediate to intermediate. They were randomly assigned to groups of American or British English. To avoid any negative effect of listening comprehension tests on the completion of questionnaires, the attitude-focused survey was given before the test of listening comprehension. Twenty minutes were given for questionnaires and another 20 minutes for listening comprehension tests. Subsequently, answer sheets underwent a scoring process whereby a correct answer would be given one point, and the full score was 20 points.

\section{Results}

In this section, we will discuss the results of the statistical analysis of the data obtained in the experiment. The results of listening comprehension tests will be presented before the discussion of questionnaires.

\section{Listening Comprehension Tests}

An independent samples t-test was conducted on the listening comprehension test, and the results are shown in Table 1. In the table, we can see that there was no significant difference between groups assigned to American and British English, $t(149)=.815, p>.05$, but the mean score of the American English group was slightly higher than that of the British English group. That is to say, the participants listening to British English could understand British English as well as subjects did with American English even though this group of EFL learners did not have much experience with British English. Therefore, the answer to Research Question 1 is that there is no significant difference between students' listening comprehension ability of American and British English.

Table 1

Independent Sample T-Test Analysis on Listening Comprehension Tests

\begin{tabular}{llllll}
\hline Group & $\mathrm{N}$ & Mean & SD & t & Sig. \\
\hline American English & 77 & 11.88 & 3.256 & .815 & .416 \\
British English & 74 & 11.47 & 2.906 & & .4 \\
\hline
\end{tabular}

Notes. The full score is 20 .

\section{Questionnaires}

One hundred and fifty-one subjects participated in this research, and the descriptive analysis of personal background is shown in Table 2 . We can see that more female students $(N=109,72 \%)$ than male students $(N=$ $42,28 \%)$ took part in this research. Also, many more English majors $(N=127,86 \%)$ than non-English majors $(N=21,14 \%)$ were involved in the study. For their first exposure to English, over half of the participants started learning English in elementary school $(N=81,54 \%)$, and over one third were exposed to English earlier in kindergarten $(N=53,35 \%)$. This reflects that English education in Taiwan is highly valued and implemented early in children's education. As for the English learning model in Taiwan, the results followed our expectation that an overwhelming amount of participants were taught American English $(N=129,88 \%)$, because American English was officially prescribed as the main model. 
Table 2

Descriptive Analysis of Personal Background

\begin{tabular}{llll}
\hline & & Frequency & Percentage \\
\hline \multirow{2}{*}{ Gender } & Male & 42 & $28 \%$ \\
& Female & 109 & $72 \%$ \\
\hline \multirow{2}{*}{ Major } & English & 127 & $86 \%$ \\
& Non-English & 21 & $14 \%$ \\
\hline \multirow{2}{*}{ First exposure } & Kindergarten & 53 & $35 \%$ \\
& Elementary school & 81 & $54 \%$ \\
\hline \multirow{2}{*}{ English model } & Junior high & 17 & $11 \%$ \\
& British & 17 & $12 \%$ \\
& American & 129 & $88 \%$ \\
& Others & 1 & $0.7 \%$ \\
\hline
\end{tabular}

In spite of the partiality toward American English, we were also interested to know whether participants had had contact with other English varieties. While $92 \%$ of them $(N=139)$ had had contact with American English, $69 \%$ of them $(N=104)$ had had exposure to British English, and $43 \%(N=65)$ to other dialects. As shown in Table 3, we also found that the students' exposure to American English was almost on a daily basis, to British English more on a weekly basis, and to all other dialects roughly on a monthly basis. This finding actually illustrates the popularity and availability of different English models in Taiwan.

Table 3

Subjects' Exposure to Varieties of English

\begin{tabular}{llll}
\hline Varieties of English & Exposure frequency & Number of cases & Case percentage \\
\hline \multirow{2}{*}{ Exposure to } & Every day & 26 & $17 \%$ \\
British English & Every week & 51 & $34 \%$ \\
& Every month & 27 & $18 \%$ \\
& Total & 104 & $69 \%$ \\
\hline \multirow{2}{*}{ Exposure to } & Every day & 69 & $46 \%$ \\
American English & Every week & 53 & $35 \%$ \\
& Every month & 17 & $11 \%$ \\
& Total & 139 & $92 \%$ \\
Exposure to & Every day & 4 & $3 \%$ \\
other dialects & Every week & 11 & $7 \%$ \\
& Every month & 50 & $33 \%$ \\
& Total & 65 & $43 \%$ \\
\hline
\end{tabular}

A reliability test was also conducted on the questions in sections 2 and 3, and the results are shown in Table 4. The last question in each section was excluded from the reliability test because they were designed to reveal the modes that participants employed to experience varieties of English. The values of Cronbach $\alpha$ were over 0.8, indicating that their responses were reliable. Comparatively, the mean and item means of the British English section were lower than those of the American English section, meaning that this group of participants had more favorable attitudes towards American English. Moreover, in order to find any differences between learners' attitudes towards American and British English, we added the scores from question 1 to question 9 for American $(M=33.69, S D=5.657)$ and British English $(M=29.16, S D=6.367)$, respectively, and conducted a paired-sample t-test on both scores, finding a significant result, $t(150)=6.727, p<.001$. It means that 
Taiwanese EFL learners had significantly favorable attitudes towards American English. This provides the answer to research question 2 .

Table 4

Reliability Test and Descriptive Analysis for Each Section of Questionnaires

\begin{tabular}{llllll}
\hline Sections & N & Mean & SD & Item mean & $\alpha$ \\
\hline (1) American English & 9 & 33.69 & 5.657 & 3.743 & .902 \\
(2) British English & 9 & 29.16 & 6.367 & 3.240 & .893 \\
Total & 18 & 62.85 & 8.752 & 3.492 & .858 \\
\hline
\end{tabular}

In order to find any association between listening comprehension ability and attitudes towards American and British English, Pearson correlation tests were conducted separately for the American and British English groups. The results of descriptive analysis of listening comprehension ability and attitudes towards American and British English are shown in Table 5. In the group of American English, of interest was the relationship between listening comprehension ability and learners' attitudes towards American English. However, no significance was found, $r(149)=.190, p>.05$. Similarly in the group of British English, the correlation of listening comprehension ability and learners' attitudes towards British English was not significant, $r(149)$ $=.128, p>.05$. Accordingly, we can say that learners' attitudes towards these two varieties of English were not associated with their listening comprehension ability of these two varieties. That is, no affirmative answer was found to Research Question 3.

Table 5

Descriptive Analysis of Listening Comprehension Ability and Attitudes Towards American and British English

\begin{tabular}{lllllll}
\hline & \multicolumn{3}{c}{ American English } & \multicolumn{3}{c}{ British English } \\
\cline { 2 - 7 } & $\mathrm{N}$ & Mean & SD & $\mathrm{N}$ & Mean & SD \\
\hline Listening comprehension score & 77 & 11.88 & 3.256 & 74 & 11.47 & 2.906 \\
Attitudes towards American English & 77 & 33.48 & 5.607 & 74 & 33.91 & 5.739 \\
Attitudes towards British English & 77 & 29.21 & 6.313 & 74 & 29.11 & 6.465 \\
\hline
\end{tabular}

Finally, we were also interested to know the modes by which participants experience or learn British and American English. This question listed five kinds of modes and multiple responses were allowed. The results are shown in Table 6. For American English, more participants accessed American English via "school education" $(N=129,92 \%)$, followed by "internet" $(N=113,80 \%)$. On the other hand, more participants accessed British English via "television" $(N=94,71 \%)$, followed by "internet" $(N=91,68 \%)$. These results truthfully reflect what was expected: that American English is the major learning model in Taiwan and the Internet provides another opportunity to learn English for EFL learners.

Table 6

Differential Modes of Experiencing American and British English

\begin{tabular}{lllllll}
\hline & \multicolumn{3}{c}{ American English } & \multicolumn{3}{c}{ British English } \\
\cline { 2 - 6 } & Frequency & Response percentage & Case percentage Frequency & Response percentage & Case percentage \\
\hline Television & 111 & $23 \%$ & $79 \%$ & 94 & $27 \%$ & $71 \%$ \\
Broadcast & 69 & $14 \%$ & $49 \%$ & 43 & $12 \%$ & $32 \%$ \\
School & 129 & $26 \%$ & $92 \%$ & 81 & $23 \%$ & $61 \%$ \\
Internet & 113 & $23 \%$ & $80 \%$ & 91 & $26 \%$ & $68 \%$ \\
NS & 71 & $14 \%$ & $50 \%$ & 43 & $12 \%$ & $32 \%$ \\
\hline
\end{tabular}

Notes. NS: native speakers. 


\section{Conclusion}

Although there is no significant difference between students' performance in listening comprehension of American and British English, suggestions are provided for English language teaching and implications drawn for the concept of English as an International Language (EIL) and English as a Lingua Franca (ELF).

First of all, pedagogical practice that involves only a single English model may need modification. It has been mentioned that, due to the close relationship and frequent contact between the United States and Taiwan in political, economic, and cultural affairs, American English is predominantly prescribed as the English learning model, and hence there is limited opportunity for Taiwanese EFL learners to learn or experience British English. Taiwanese EFL learners do have difficulties understanding British English, at least during initial encounters. Opportunities should therefore be provided for learners to, at least, experience British English. That means the inclusion of British English in curriculum and teaching materials should be considered (S. Kawanami \& K. Kawanami, 2010). The change in pedagogic practice will undoubtedly challenge English language teachers' knowledge of English varieties. Taiwanese ELT professionals should consider the proposal made by Benson decades ago that American English was emerging as another influential variety of English (Benson, 1989). He suggested that TESOL programs should need to include the differences between American and British English as targets of instruction, and that systematic comparisons of these two major English varieties should be conducted to this end.

It is indisputable that English has become an international language and a huge number of non-native learners have strived to acquire the lingua franca to pursue global communication. The concepts of English as an International Language (EIL) and English as a Lingua Franca (ELF) have been well recognized, and the requirement of international communication and mobility is imposed on younger generations (Jenkins, 2006; S. Kawanami \& K. Kawanami, 2010; Suzuki, 2011). A fundamental purpose of learning English is to communicate successfully with people of various L1 languages. The predominance of a single English learning model may lead to the danger of input poverty and deprive EFL learners of their tickets to success in international communication. To go one step further, the understanding of various English accents, including native and non-native, holds the key to effective communication. As Scales et al. argue, knowledge and experience with various English accents not only improves listening comprehension, but enhances mutual intelligibility and communicative efficacy (Scales et al., 2006). Matsuda also pointed out that the instruction of inner-circle English dialects would not be sufficient to cope with the demand in global communication (Matsuda, 2003). However, a more sophisticated issue is that, while the legitimate status of outer-circle or expanding circle in language classrooms against inner-circle English (Kachru, 1992) are acknowledged, language teachers and learners all hesitate between the strong desire to learn standard English and the intention to assert their local version of English in its own right (Timmis, 2002; Jenkins, 2009).

In line with previous studies, this research also reveals the notable influence of mass media on language learning. The ubiquity of mass media, including broadcast and digital media, brings about innovative language learning environments. As such media can provide genuine and prompt access to various English accents, language learning can take place anytime and anywhere. How to exploit these learning "tools" for language learning will be the critical mission of pedagogic practice in the new century. 


\section{References}

Alftberg, A. (2009). British or American English? Attitudes, awareness and usage among pupils in a secondary school. Retrieved January 20, 2015 from www.diva-portal.org/smash/get/diva2:241524/FULLTEXT01.pdf

Benson, M. (1989). Differences between American English and British English: A challenge to TESOL. TESOL Quarterly, 23(2), 351-355.

Chen, P. (2010). An investigation of differences in listening test performance and listening strategy use between American and British English by Taiwanese college English majors (Master thesis, Southern Taiwan University of Science and Technology, R.O.C.).

Dalton-Puffer, C., Kaltenboeck, G., \& Smit, U. (1997). Learner attitudes and L2 pronunciation in Austria. World Englishes, 16(1), 115-128.

Heeren, K. D. (2012). The effect of an unfamiliar accent on Taiwanese students' listening comprehension (Ph.D. thesis, National Kaohsiung Normal University, R.O.C.).

Jenkins, J. (2006). Current perspectives on teaching world Englishes and English as a lingua franca. TESOL Quarterly, 40(1), 157-181.

Jenkins, J. (2009). English as a lingua franca: Interpretations and attitudes. World Englishes, 28(2), 200-207.

Jenkins, J. (2012). English as a lingua franca from the classroom to the classroom. ELT Journal, 66(4), 486-494.

Kachru, B. (1992). The other tongue. Chicago: University of Illinois Press.

Kawanami, S., \& Kawanami, K. (2010). Japanese learners' perception and attitudes toward English accents. LET Kyushu-Okinawa Bulletin, 10, 1-14.

Ladegaard, H. J. (1998). National stereotypes and language attitudes: The perception of British, American and Australian language and culture in Denmark. Language and Communication, 18(4), 251-274.

Major, R. C., Fitzmaurice, S. M., Bunta, F., \& Balasubramanian, C. B. (2005). Testing the effects of regional, ethnic, and international dialects of English on listening comprehension. Language Learning, 55(1), 37-69.

Matsuda, A. (2003). Incorporating world Englishes in teaching English as an international language. TESOL Quarterly, 37(4), 719-729.

Matsuura, H., Chiba, R., \& Fujieda, M. (1999). Intelligibility and comprehensibility of American and Irish Englishes in Japan. World Englishes, 18(1), 49-62.

Mompean, R. A. (1997). Pronouncing English in Brazil. English Today, 13(1), 28-35.

Östlund, F. (2005). British vs. American English: Pronunciation in the EFL classroom. Retrieved January 20, 2015 from www.diva-portal.org/smash/get/diva2:5955/FULLTEXT01.pdf

Rasmussen, H. F. (2015). Britannia still rules the waves: Norwegian teachers' and students' attitudes to British English and American English (Master thesis, University of Bergen, Norway).

Safaa, A. (2015). British vs. American English for university students teaching purposes: The case of third-year EFL students at Tlemcen University (Master thesis, University of Tlemcen, Alberia).

Scales, J., Wennerstrom, A., Richard, D., \& Wu, S. H. (2006). Language learners' perceptions of accent. TESOL Quarterly, 40(4), 715-738.

Suzuki, A. (2011). Introducing diversity of English into ELT: Student teachers' responses. ELT Journal, 65(2), 145-153.

Timmis, I. (2002). Native speaker norms and International English: A classroom view. ELT journal, 56(3), 240-249. 
Appendix: Questionnaire of Attitudes American and British English (English Version)

\section{Part 1: Personal Background}

1. Gender: $\square$ male $\square$ female

2. Is English your major study? $\square$ Yes $\square$ No

3. When did you start to learn English? Since

$\square$ Kindergarten $\square$ Elementary school $\square$ Junior high school

4. What is the major English learning model?

$\square$ American English $\square$ British English $\square$ Other Dialects (Australian or Canadian)

5. Are you currently exposed to the following English varieties in regular?

(1) American English 口every day 口every week 口every month

(2) British English 口every day घevery week घevery month

(3) Other Dialects aevery day aevery week aevery month

\section{Part 2: Attitudes Towards American English}

1. I have frequent contacts with American English in daily life.

2. We use/learn American English in class.

3. I am familiar with the phonetic system of American English.

4. I think American English can reinforce my motivation to learn English.

5. I prefer the official status of American English.

6. I think the pronunciation of American English is clear.

7. I think American English is easy to understand.

8. I think the pronunciation of American English is very fascinating.

9. I think American English is highly practical.

10. I have contacts with American English via

(1) television (2) broadcasting (3) schools

(4) Internet (5) American native speakers

\section{Part 3: Attitudes Towards British English}

1. I have frequent contacts with British English in daily life.

2. We use/learn British English in class.

3. I am familiar with the phonetic system of British English.

4. I think British English can reinforce my motivation to learn English.

5. I prefer the official status of British English.

6. I think the pronunciation of British English is clear.

7. I think British English is easy to understand.

8. I think the pronunciation of British English is very fascinating.

9. I think British English is highly practical.

10. I have contacts with British English via

(1) television (2) broadcasting (3) schools (multiple responses allowed).

(4) Internet (5) British native speakers 